\title{
Efektivitas metode pembelajaran PQ4R ditinjau dari kemampuan berpikir reflektif matematis dan self-concept siswa
}

\author{
Intan Permatasari ${ }^{1 *}$, Sri Hastuti Noer ${ }^{1}$ (i), Pentatito Gunowibowo ${ }^{1}$ \\ ${ }^{1}$ Program Studi Pendidikan Matematika, Universitas Lampung, Bandar Lampung, Indonesia \\ * Corresponding Author. E-mail: permataintan100@yahoo.com
}

\begin{tabular}{ll}
\hline \multicolumn{1}{c}{ ARTICLE INFO } & \multicolumn{1}{c}{ ABSTRACT } \\
\hline Article History: & Penelitian eksperimen semu ini bertujuan untuk menguji efektivitas metode pembelajaran \\
Received: 10 Aug. 2020 & PQ4R (Preview, Question, Read, Reflect, Recite, Review) ditinjau dari kemampuan berpikir reflek- \\
Revised: 22 Sept. 2020 & tif dan self-concept siswa. Populasi penelitian adalah seluruh siswa kelas VIII SMP Negeri 12 \\
Accepted: 4 Nov. 2020 & Bandar Lampung tahun pelajaran 2019/2020 yang terdistribusi dalam sembilan kelas. Dari sem- \\
& bilan kelas tersebut dipilih satu kelas sebagai kelas eksperimen dan satu kelas sebagai kelas kon- \\
Keywords: & trol. Desain penelitian yang digunakan adalah pretest-posttest control group design. Pengum- \\
Metode pembelajaran & pulan data dilakukan menggunakan tes kemampuan berpikir reflektif matematis dan angket \\
PQ4R, & self-concept siswa. Data hasil tes dan angket dianalisis secara deskriptif dan inferensial. Hasil \\
Kemampuan berpikir & penelitian menunjukkan bahwa persentase siswa pada kelas PQ4R dengan kemampuan \\
reflektif matematis, & berpikir reflektif matematis dan self-concept terkategori baik lebih dari 60\% dari jumlah siswa, \\
Self-concept siswa, PQ4R & namun peningkatan kemampuan berpikir reflektif matematis dan self-concept siswa yang \\
learning methods, & mengikuti pembelajaran PQ4R tidak lebih tinggi daripada peningkatan siswa yang mengikuti \\
Mathematical reflective & pembelajaran konvensional. Dengan demikian, dapat disimpulkan bahwa metode pembe- \\
thinking skills, & lajaran PQ4R tidak efektif ditinjau dari kemampuan berpikir reflektif matematis dan self-concept \\
Students'self-concept. & siswa.
\end{tabular}

This quasi-experimental research aimed to examine the effectiveness of the PQ4R (Preview, Question, Read, Reflect, Recite, Review) learning method in terms of reflective thinking ability and self-concept of students. The study population was all eighth-grade students of SMP Negeri 12 Bandar Lampung (Junior High School) for the 2019/2020 academic year, distributed in nine classes. Of the nine classes, one class was selected as the experimental class and one class as the control class. The research design used was the pretest-posttest control group design. The data was collected using a test of reflective mathematical thinking skills and a students' self-concept questionnaire. Test and questionnaire results were analyzed descriptively and inferentially. The results showed that the percentage of students in the PQ4R class with good categories in reflective mathematical thinking and self-concept was more than $60 \%$ of students' total number. The increase in mathematical reflective thinking ability and self-concept of students who took $P Q 4 R$ learning was not higher than the increase in students who follow conventional learning. Thus, it can be concluded that the PQ4R learning method was ineffective in terms of students' mathematical reflective thinking skills and self-concept.

This is an open access article under the CC-BY-SA license (c) (i) (?)

\section{How to Cite:}

Permatasai, I., Noer, S. H., \& Gunowibowo, P. (2020). Efektivitas metode pembelajaran PQ4R ditinjau dari kemampuan berpikir reflektif matematis dan self-concept siswa. Pythagoras: Jurnal Pendidikan Matematika, 15(1), 61-72. https://doi.org/10.21831/pg.v15i1.33830

https://doi.org/10.21831/pg.v15i1.33830

\section{PENDAHULUAN}

Seiring berkembangnya zaman, ilmu pengetahuan dan teknologi pun semakin berkembang pesat. Perkembangan tersebut membawa manusia memasuki era persaingan global yang semakin ketat. Agar seseorang mampu bersaing dalam era globalisasi, maka dibutuhkan sumber daya manusia dengan kualitas sesuai dengan standar yang dibutuhkan masyarakat global serta mampu beradaptasi seiring dengan perubahan-perubahan yang terjadi. 
Salah satu upaya yang harus dilakukan guna meningkatkan kualitas sumber daya manusia adalah melalui pendidikan. Melalui pendidikan, seseorang diharapkan mampu mengembangkan potensi dirinya secara optimal sehingga menjadi pribadi yang berkualitas dan mampu bersaing dalam menghadapi pesatnya perkembangan ilmu pengetahuan dan teknologi di era globalisasi. Selain itu, pendidikan juga mempunyai peranan penting bagi pengembangan bangsa dan negara. Hal ini dijelaskan oleh Suntoro (2009) bahwa pendidikan mempunyai peranan yang sangat menentukan bagi perkembangan dan perwujudan diri individu, terutama bagi perkembangan bangsa dan negara, sebab dari situlah akan tercipta sumber daya manusia yang berkualitas.

Salah satu proses yang penting dilakukan guna tercapainya tujuan pendidikan adalah pembelajaran. Dalam Undang-Undang Nomor 20 Tahun 2003 tentang Sistem Pendidikan Nasional (Republik Indonesia, 2003) disebutkan bahwa pembelajaran adalah proses interaksi peserta didik dengan pendidik dan sumber belajar pada suatu lingkungan belajar. Hal ini sejalan dengan pendapat Rusman (2012) yang mengemukakan pendapat bahwa pembelajaran pada hakikatnya merupakan suatu proses interaksi antara pendidik dengan peserta didik, baik secara langsung maupun secara tidak langsung. Selain itu, Sudjana (2004) menyatakan bahwa pembelajaran dapat diartikan sebagai upaya sistematik dan sengaja untuk menciptakan kegiatan interaksi edukatif antara dua pihak, yaitu antara peserta didik (warga belajar) dan pendidik (sumber belajar) yang melakukan kegiatan pembelajaran. Dengan demikian, pembelajaran merupakan suatu proses interaksi edukatif antara peserta didik dengan pendidik dan sumber belajar yang dilakukan secara langsung maupun secara tidak langsung pada suatu lingkungan belajar.

Matematika adalah salah satu mata pelajaran wajib yang diajarkan dalam pembelajaran di setiap jenjang pendidikan formal (Presiden Republik Indonesia, 2013). Kline (Noer, 2017) menyatakan bahwa matematika itu bukan pengalaman menyendiri yang dapat sempurna karena dirinya sendiri, tetapi adanya matematika itu terutama untuk membantu manusia dalam memahami dan menguasai permasalahan sosial, ekonomi, dan alam. Selain itu, Noer (2017) mengungkapkan bahwa matematika sebagai ratu ilmu yang artinya matematika sebagai alat pelayanan ilmu yang lain. Matematika tumbuh dan berkembang untuk dirinya sendiri sebagai suatu ilmu, juga untuk melayani kebutuhan ilmu pengetahuan dalam pengembangan dan operasionalnya. Hal tersebut menunjukkan bahwa belajar ilmu matematika adalah hal yang penting.

Pentingnya pembelajaran matematika disebutkan dalam Permendikbud Nomor 58 Tahun 2014 (Kemendikbud, 2014) bahwa tujuan pembelajaran matematika di antaranya agar siswa mampu berpikir secara sistematis, deduktif, teliti, dan cermat. Siswa diharapkan mampu memahami konsep-konsep matematika, menjelaskan keterkaitan antar konsep dan menggunakan konsep maupun algoritma secara luwes, akurat, efisien, dan tepat dalam penyelesaian masalah. Untuk mencapai tujuan pembelajaran matematika tersebut diperlukan kemampuan berpikir tingkat tinggi (Apino \& Retnawati, 2017; Jailani et al., 2017; Retnawati et al., 2018). Salah satunya yaitu kemampuan berpikir reflektif. Berpikir reflektif berperan penting sebagai sarana untuk mendorong pemikiran selama situasi pemecahan masalah (Angkotasan, 2013; Suharna, 2012). Hal ini disebabkan kemampuan berpikir reflektif memberikan kesempatan untuk belajar serta memikirkan strategi terbaik untuk mencapai tujuan pembelajaran. Dengan demikian, dapat disimpulkan bahwa kemampuan berpikir reflektif merupakan salah satu kemampuan yang harus dimiliki oleh siswa supaya dapat mencapai tujuan pembelajaran matematika.

Menurut Fuady (2017) berpikir reflektif adalah proses berpikir dengan menghubungkan pengetahuan yang dimiliki dan yang sedang dipelajari dalam menganalisis masalah, mengevaluasi, menyimpulkan dan memutuskan penyelesaian terbaik terhadap masalah yang diberikan. Selain itu, Nuriadin et al. (2015) berpendapat bahwa berpikir reflektif adalah sebuah proses berpikir yang melibatkan keterampilan mental dalam memecahkan masalah, mengidentifikasi tentang segala sesuatu yang diketahui, melakukan modifikasi pemahaman, dan menerapkan hasil yang diperoleh dalam situasi lain. Sejalan dengan itu, Noer (2010) mengemukakan bahwa kemampuan berpikir reflektif adalah kemampuan mengidentifikasi apa yang sudah diketahui, menerapkan pengetahuan matematis yang dimiliki dalam situasi yang lain, dan memodifikasi pemahaman berdasarkan informasi dan pengalamanpengalaman baru dalam menyelesaikan masalah. Lebih lanjut, Noer (2010) mengatakan bahwa berpikir reflektif meliputi tiga indikator atau fase, yaitu: (a) reacting, yaitu bereaksi dengan perhatian pribadi terhadap peristiwa atau situasi atau masalah matematis dengan berfokus pada sifat alami situasi; (b) comparing, yaitu berpikir yang berpusat pada analisis dan klarifikasi pengalaman individual, makna, dan asumsi-asumsi untuk mengevaluasi tindakan-tindakan dan apa yang diyakini dengan cara membandingkan reaksi dengan pengalaman lain; dan (c) contemplating, yaitu proses berpikir yang mengutamakan pembangunan pemahaman diri yang mendalam terhadap permasalahan dalam pembelajaran matematika. Deringol (2019) mengatakan bahwa semakin tinggi kemampuan berpikir reflektif siswa maka akan semakin tinggi prestasi belajar matematika yang di capainya. 
Dengan demikian, berpikir reflektif merupakan suatu komponen penting yang perlu dikembangkan dalam proses pembelajaran.

Akan tetapi, pada kenyataannya kemampuan berpikir reflektif siswa Indonesia masih tergolong rendah. Salah satu indikasinya ditunjukkan dari rendahnya capaian siswa Indonesia pada studi PISA (Programme for International Student Assessment). Pada studi PISA 2018 siswa Indonesia berada di peringkat 72 dari 78 negara dengan rata-rata skor kemampuan matematis sebesar 379 (OECD, 2019). Dalam studi PISA, literasi matematika pada difokuskan pada kemampuan siswa dalam menganalisis, memberikan alasan, dan menyampaikan ide secara efektif, merumuskan, merencanakan dan menginterpretasikan masalah-masalah matematika dalam berbagai bentuk dan situasi. Rahmawati (2016) menyatakan bahwa salah satu faktor penyebab rendahnya hasil PISA siswa Indonesia kurang terlatih dalam menyelesaikan soal-soal yang substansinya masalah konstektual, menuntut penalaran, argumentasi, dan kreativitas, serta mengharuskan siswa dapat memahami maksud soal terlebih dahulu sebelum menyelesaikannya. Kemampuan-kemampuan tersebut erat kaitannya dengan kemampuan berpikir reflektif matematis siswa. Dengan demikian, peningkatan kemampuan berpikir reflektif perlu dilakukan.

Selain kemampuan berpikir reflektif, dalam proses pembelajaran matematika terdapat aspek psikologi yang juga perlu dikembangkan untuk menunjang proses pembelajaran. Pembelajaran akan lebih berhasil ketika kemampuan kognitif dan psikologis siswa dikembangkan bersama-sama. Salah satu aspek psikologis tersebut adalah selfconcept atau konsep diri. Self-concept dalam penelitian ini adalah self-concept terhadap matematika (mathematics self-concept). Menurut Douglas (Triana, 2017) mathematics self-concept adalah penilaian atau pandangan seseorang mengenai kemampuannya untuk belajar matematika. Sedangkan Peteros et al. (2020) mengatakan bahwa self-concept dalam matematika dapat didefinisikan sebagai penilaian siswa atas keterampilan, kemampuan, kesenangan, dan minat pada matematika yang dipandang sebagai faktor penting dalam pencapaian mereka dalam belajar matematika. Sejalan dengan hal itu, Siregar dan Humairo (2018) berpendapat bahwa self-concept secara tidak langsung mempengaruhi prestasi belajar siswa. Hal ini dapat terjadi melalui pandangan siswa tentang dirinya sendiri. Jika siswa memandang dirinya sebagai orang yang memiliki kemampuan cukup untuk melaksanakan suatu tugas, maka tingkah laku siswa tersebut akan menunjukkan kemampuannya. Begitu pula sebaliknya, jika siswa melihat dirinya sebagai orang yang tidak memiliki kemampuan yang cukup untuk melaksanakan suatu tugas, maka perilaku siswa tersebut akan menunjukkan ketidakmampuannya.

Menurut Colhoun dan Acocella (Ghufron \& Risnawati, 2010) terdapat tiga dimensi self-concept yaitu: (1) pengetahuan (kognitif), mencakup apa yang kita tahu tentang diri kita sendiri yang akan memberikan gambaran tentang diri sendiri; (2) harapan, merupakan pandangan individu terhadap dirinya yang dicita-citakan di masa depan; dan (3) penilaian, merupakan penilaian individu terhadap dirinya sendiri. Supriyanti (Triana, 2017) mengemukakan bahwa self-concept yang positif dibutuhkan dalam proses pembelajaran matematika untuk mencapai tujuan pembelajaran yang hendak dicapai karena self-concept berkolerasi dengan motivasi, prestasi dan ketertarikan seseorang terhadap matematika. Ketika seorang siswa memiliki self-concept yang tinggi, maka ia akan tertarik untuk mempelajari matematika sehingga pembelajaran matematika akan menjadi suatu hal yang menyenangkan. Selain itu, siswa akan yakin dengan kemampuan matematis yang dimilikinya, sehingga ia akan optimis dapat menyelesaikan permasalahan matematika yang diberikan. Oleh karena itu, sangat penting bagi siswa untuk mengembangkan self-concept dalam pembelajaran matematika.

Mengingat pentingnya kemampuan berpikir reflektif dan self-concept dimiliki oleh siswa dalam pembelajaran matematika, maka perlu dilakukan upaya untuk memperbaiki dan meningkatkan mutu pembelajaran matematika, salah satunya dengan melakukan inovasi dalam pembelajaran. Inovasi tersebut salah satunya dapat diawali dengan memaksimalkan potensi siswa. Di dalam pembelajaran matematika tidak hanya kemampuan penggunaan rumus saja yang diperlukan, tetapi kemampuan membaca juga penting untuk membantu siswa agar dapat memahami isi materi yang dipelajari. Dalam proses pembelajaran, membaca menjadi kegiatan yang paling mendasar yang dilakukan siswa untuk mengetahui informasi yang belum mereka ketahui sebelumnya. Membaca dapat membantu keberhasilan siswa dalam mempelajari berbagai bidang studi termasuk matematika. Sejalan dengan hal itu, Wungkana (2016) mengemukakan bahwa pada semua jenjang pendidikan, kemampuan membaca menjadi prioritas yang harus dikuasai siswa. Untuk dapat memahami suatu teks bacaan dengan baik diperlukan kemampuan membaca pemahaman dengan baik (Inawati \& Sanjaya, 2018). Menurut Subyantoro (2011) membaca pemahaman merupakan jenis membaca dengan penuh pemahaman untuk menemukan gagasan/ide pokok yang terdapat dalam bacaan, sehingga pembaca dapat memperoleh informasi dan memahami bacaan dengan baik. 
Salah satu metode yang paling banyak dikenal untuk membantu siswa memahami dan mengingat materi yang mereka baca adalah metode pembelajaran PQ4R (Preview, Question, Read, Reflect, Recite, Review).

Menurut Suprijono (2013), metode pembelajaran $P Q 4 R$ ini meliputi enam tahap yang berkesinambungan, yaitu: (1) preview, yaitu membaca selintas dengan cepat (judul, sub judul, topik, dan kalimat pertama); (2) question, yaitu merumuskan pertanyaan-pertanyaan kepada diri sendiri mengenai bahan bacaan; (3) read, yaitu membaca aktif dan detail; (4) reflect, yaitu selama membaca siswa mencari jawaban atas pertanyaan yang sudah dibuat dan memahami informasi yang ada pada bacaan tersebut; (5) recite, yaitu merenungkan kembali informasi yang telah dipelajari; dan (6) review, yaitu mengulang secara menyeluruh bahan bacaan. Menurut Trianto (2015), metode pembelajaran $P Q 4 R$ digunakan untuk membantu siswa mengingat apa yang mereka baca dan membantu siswa memahami pembelajaran dengan kegiatan membaca materi pembelajaran. Pabalik et al. (2020) berpendapat bahwa PQ4R adalah strategi yang dapat membantu siswa untuk memahami dan mengingat apa yang mereka baca. Dengan enam langkah pembelajaran yaitu preview, question, read, reflect, recite, dan review diharapkan dapat meningkatkan kemampuan membaca pemahaman siswa, termasuk dalam pembelajaran matematika.

Beberapa penelitian terdahulu telah dilakukan untuk menguji dampak penerapan metode pembelajaran $P Q 4 R$ dalam pembelajaran matematika. Hasil penelitian Yulianti et al. (2016) menyimpulkan bahwa metode pembelajaran $P Q 4 R$ mampu meningkatkan pemahaman konsep siswa melalui aktivitas membaca bahan ajar yang disediakan oleh guru. Selain itu, Novalia dan Noer (2019) menyimpulkan bahwa metode PQ4R mampu meningkatkan kemampuan berpikir kreatif dan kemandirian belajar siswa. Penelitian-penelitian tersebut hanya fokus pada penerapan metode $P Q 4 R$ untuk meningkatkan kemampuan pemahaman konsep, kemampuan berpikir kreatif, dan komunikasi matematika, sedangkan kaitannya dengan kemampuan berpikir reflektif dan self-concept siswa belum dilakukan. Dalam hal ini, peneliti tertarik untuk menyelidiki pengaruh metode pembelajaran $P Q 4 R$ terhadap kemampuan berpikir reflektif matematis siswa dan self-concept siswa. Penerapan metode $P Q 4 R$ tersebut diharapkan efektif ditinjau dari kemampuan berpikir reflektif matematis dan self-concept siswa. Oleh karena itu, penelitian ini bertujuan untuk mendeskripsikan efektivitas metode pembelajaran PQ4R ditinjau dari kemampuan berpikir reflektif matematis dan self-concept siswa.

\section{METODE}

Penelitian ini merupakan penelitian eksperimen semu (quasi experiment) dengan variabel bebas adalah metode pembelajaran ( $P Q 4 R$ dan pembelajaran konvensional), sedangkan variabel terikatnya adalah kemampuan berpikir reflektif dan self-concept siswa. Desain yang digunakan dalam penelitian ini adalah pretest-posttest control group design. Penelitian dilaksanakan pada semester genap tahun pelajaran 2019/2020 di SMP Negeri 12 Bandar Lampung. Populasi dalam penelitian ini adalah semua siswa kelas VIII yang terdiri dari sembilan kelas yaitu kelas VIII A sampai VIII I. Pengambilan sampel dilakukan dengan teknik purposive sampling. Pertimbangan yang digunakan yaitu sampel yang diambil diajar oleh guru yang sama dan mendapat perlakuan yang sama dari guru tersebut dalam kegiatan belajar, sehingga memiliki pengalaman belajar yang relatif sama. Kemudian pemilihan kelas eksperimen dan kelas kontrol dilakukan melalui pengundian. Terpilihlah kelas VIII C dengan jumlah 30 siswa sebagai kelas eksperimen, yaitu kelas yang menggunakan metode pembelajaran $P Q 4 R$ dan kelas VIII D dengan jumlah 30 siswa sebagai kelas kontrol, yaitu kelas yang menggunakan pembelajaran konvensional.

Teknik pengumpulan data yang digunakan dalam penelitian ini yaitu teknik tes dan nontes. Penelitian ini menggunakan dua jenis instrumen penelitian, yaitu tes untuk mengukur kemampuan berpikir reflektif matematis dengan indikator yaitu reacting, comparing, dan contemplating dan nontes untuk mengukur self-concept siswa terhadap pembelajaran matematika. Bentuk instrumen tes adalah soal uraian yang terdiri dari empat butir soal pada materi Lingkaran. Sedangkan bentuk instrumen nontes yang digunakan adalah angket self-concept yang terdiri dari 20 butir pernyataan yang mencangkup tiga dimensi self-concept yaitu pengetahuan, harapan, dan penilaian. Angket memuat pernyataan positif dan negatif. Angket menggunakan skala Likert yang terdiri dari empat pilihan jawaban yaitu, sangat setuju, setuju, tidak setuju, dan sangat tidak setuju.

Validitas instrumen tes dan angket pada penelitian ini didasarkan pada validitas isi. Pembuktian validitas dalam penelitian ini dilakukan melalui penilaian terhadap kesesuaian isi instrumen tes dengan kisi-kisi instrumen yang diukur dan kesesuaian bahasa yang digunakan dengan kemampuan bahasa siswa. Pembuktian validitas isis menggunakan daftar checklist yang dilakukan oleh guru mitra mata pelajaran matematika kelas VIII. Hasil penilaian guru menunjukkan bahwa instrumen yang digunakan telah layak digunakan. Setelah instrumen tes dan angket dinyatakan valid maka instrumen-instrumen tersebut diujicobakan kepada siswa selain sampel, yaitu siswa kelas IX 
C dengan pertimbangan siswa kelas tersebut telah menempuh materi yang diujicobakan, yaitu materi Lingkaran. Selanjutnya dilakukan estimasi reliabilitas instrumen tes dan angket. Khusus untuk instrumen tes juga dilakukan analisis daya pembeda dan tingkat kesukaran butir tes.

Koefisien reliabilitas instrumen tes dan angket secara berturut-turut yaitu 0,89 dan 0,92. Arikunto (2011) menyebutkan bahwa koefisien reliabilitas di atas 0,80 dikategorikan sangat tinggi. Berdasarkan hasil tersebut dapat disimpulkan bahwa instrumen tes dan angket yang digunakan memiliki reliabilitas yang sangat tinggi. Koefisien daya pembeda untuk soal nomor 1 , 2, 3, dan 4 berturut-turut: 0,$45 ; 0,38 ; 0,58$; dan 0,53. Daya pembeda $0,30-0,39$ dikategorikan baik dan $\geq 0,40$ dikategorikan sangat tinggi (Arifin, 2012). Berdasarkan hasil tersebut dapat disimpulkan bahwa instrumen tes yang digunakan memiliki daya pembeda soal baik dan sangat baik. Indeks tingkat kesukaran untuk soal nomor 1, 2, 3, dan 4 berturut-turut yaitu 0,69;0,64;0,63; dan 0,70. Sudijono (2011) menyatakan bahwa indeks tingkat kesukaran pada rentang 0,31 - 0,70 dikategorikan sedang.

Sebelum kedua kelas sampel diberikan perlakuan yang berbeda, terlebih dahulu diberikan pretest kemampuan berpikir reflektif dan penilaian diri awal untuk self-concept siswa. Hal ini bertujuan untuk mengetahui kemampuan berpikir reflektif dan self-concept awal siswa pada kedua kelas. Selanjutnya, kedua kelas diberikan perlakuan berbeda yaitu kelas eksperimen menggunakan metode pembelajaran $P Q 4 R$ dan kelas kontrol menggunakan pembelajaran konvensional. Setelah diberikan perlakuan, kedua kelas diberi posttest untuk mengetahui kemampuan berpikir reflektif dan self-concept akhir siswa. Hasil pretest-posttest yang diperoleh kemudian dianalisis untuk mendapatkan skor peningkatan (gain) pada kedua kelas. Metode pembelajaran PQ4R dikatakan efektif jika lebih dari $60 \%$ siswa memiliki kemampuan berpikir reflektif matematis dan self-concept minimal pada kategori sedang dan peningkatan kemampuan berpikir reflektif matematis dan self-concept siswa kelas eksperimen lebih tinggi daripada kelas kontrol.

Interpretasi kategori kemampuan siswa ditentukan dengan menggunakan nilai rata-rata $(\bar{x})$ dan simpangan baku $(s)$ (Azwar, 2016). Dalam penelitian ini kategori tersebut ditentukan berdasarkan skor posttest. Kategori tinggi apabila $x \geq \bar{x}+s$; kategori sedang apabila $\bar{x}-s \leq x<\bar{x}+s$; dan kategori rendah apabila $x<\bar{x}-s$. Analisis inferensial digunakan untuk menguji hipotesis penelitian. Uji $z$ digunakan untuk menguji apakah proporsi siswa yang memiliki kemampuan berpikir reflektif dan self-concept pada kategori minimal sedang lebih dari $60 \%$. Untuk menguji perbedaan peningkatan kemampuan berpikir reflektif dan self-concept siswa digunakan uji $t$ satu sampel. Pengambilan keputusan dilakukan pada taraf signifikansi $5 \%$. Sebelum dilakukan uji hipotesis terlebih dahulu data dilakukan uji prasyarat yaitu uji normalitas dan uji homogenitas. Uji normalitas data menggunakan uji chi-kuadrat, sedangkan uji homogenitas menggunakan uji $F$.

\section{HASIL PENELITIAN}

\section{Efektivitas Model Pembelajaran PQ4R Ditinjau dari Kemampuan Berpikir Reflektif}

Deskripsi kemampuan berpikir reflektif matematis siswa yang mendapat perlakuan pembelajaran $P Q 4 R$ dan pembelajaran konvensional disajikan pada Tabel 1.

Tabel 1. Deskripsi kemampuan berpikir reflektif matematis siswa

\begin{tabular}{lcccccc}
\hline \multirow{2}{*}{ Kelas } & \multicolumn{2}{c}{ Pretest } & \multicolumn{2}{c}{ Posttest } & \multicolumn{2}{c}{ Gain } \\
\cline { 2 - 7 } & $\bar{x}$ & $s$ & $\bar{x}$ & $s$ & $\bar{x}$ & $s$ \\
\hline PQ4R & 8,07 & 3,32 & 36,10 & 3,65 & 0,70 & 0,09 \\
Konvensional & 7,53 & 2,70 & 35,20 & 5,64 & 0,68 & 0,12 \\
\hline
\end{tabular}

Berdasarkan Tabel 1 dapat diketahui bahwa rata-rata skor kemampuan berpikir reflektif matematis awal siswa pada kelas dengan pembelajaran $P Q 4 R$ lebih tinggi dibandingkan rata-rata skor kemampuan berpikir reflektif pada kelas dengan pembelajaran konvensional. Simpangan baku skor kemampuan berpikir reflektif matematis awal siswa pada kelas yang mengikuti pembelajaran $P Q 4 R$ lebih tinggi dibandingkan siswa yang mengikuti pembelajaran konvensional. Hal ini menunjukkan bahwa sebaran skor kemampuan berpikir reflektif matematis awal siswa di kelas pembelajaran $P Q 4 R$ lebih bervariasi dibandingkan siswa yang mengikuti pembelajaran konvensional. Uraian tersebut menunjukkan bahwa secara deskriptif siswa pada kedua kelas sampel memiliki kemampuan berpikir reflektif matematis yang relatif sama.

Berdasarkan Tabel 1 juga terlihat bahwa rata-rata skor kemampuan berpikir reflektif matematis akhir siswa pada kelas dengan pembelajaran $P Q 4 R$ lebih tinggi dibandingkan rata-rata skor kemampuan berpikir reflektif pada 
kelas dengan pembelajaran konvensional. Simpangan baku skor kemampuan berpikir reflektif matematis akhir siswa pada kelas yang mengikuti pembelajaran konvensional lebih tinggi dibandingkan siswa yang mengikuti pembelajaran $P Q 4 R$. Hal ini menunjukkan bahwa sebaran skor kemampuan berpikir reflektif matematis akhir siswa di kelas pembelajaran konvensional lebih bervariasi dibandingkan siswa yang mengikuti pembelajaran $P Q 4 R$.

Data peningkatan (gain) kemampuan berpikir reflektif matematis siswa diperoleh dari selisih antara skor kemampuan awal (pretest) dan skor kemampuan akhir (posttest) kemudian dibagi dengan selisih antara skor maksimal dan skor kemampuan awal (pretest). Berdasarkan Tabel 1 diketahui bahwa rata-rata gain siswa pada kelas dengan pembelajaran $P Q 4 R$ sedikit lebih tinggi dibandingkan rata-rata gain kemampuan berpikir reflektif pada kelas dengan pembelajaran konvensional. Simpangan baku gain kemampuan berpikir reflektif matematis pada kelas yang mengikuti pembelajaran konvensional sedikit lebih tinggi dibandingkan siswa yang mengikuti pembelajaran PQ4R. Hal ini menunjukkan bahwa sebaran data gain kemampuan berpikir reflektif matematis siswa yang mengikuti pembelajaran konvensional lebih bervariasi dibandingkan siswa yang mengikuti pembelajaran PQ4R.

Analisis setiap indikator dilakukan pada skor pretest dan skor posttest pada kelas eksperimen dan kelas kontrol. Adapun hasil analisis setiap indikator pada kelas eksperimen dan kelas kontrol disajikan dalam Tabel 2.

Tabel 2. Persentase pencapaian indikator kemampuan berpikir reflektif matematis

\begin{tabular}{lcccc}
\hline \multirow{2}{*}{ Indikator } & \multicolumn{2}{c}{ Pretest } & \multicolumn{2}{c}{ Posttest } \\
\cline { 2 - 5 } & $P Q 4 R$ & Konvensional & $P Q 4 R$ & Konvensional \\
\hline Reacting & $23 \%$ & $24 \%$ & $90 \%$ & $87 \%$ \\
Comparing & $20 \%$ & $19 \%$ & $67 \%$ & $71 \%$ \\
Contemplating & $2 \%$ & $3 \%$ & $68 \%$ & $60 \%$ \\
Rata-rata & $17 \%$ & $16 \%$ & $75 \%$ & $73 \%$ \\
\hline
\end{tabular}

Berdasarkan Tabel 2 terlihat bahwa pencapaian kemampuan berpikir reflektif awal siswa yang mengikuti pembelajaran $P Q 4 R$ pada indikator comparing lebih tinggi dibanding siswa yang mengikuti pembelajaran konvensional. Sedangkan kemampuan awal pada indikator reacting dan contemplating siswa yang mengikuti pembelajaran $P Q 4 R$ lebih rendah dari siswa yang mengikuti pembelajaran konvensional. Sementara untuk pencapaian kemampuan berpikir reflektif matematis akhir siswa yang mengikuti pembelajaran $P Q 4 R$ pada indikator reacting dan contemplating lebih tinggi dibandingkan siswa yang mengikuti pembelajaran konvensional. Sedangkan kemampuan akhir pada indikator comparing siswa yang mengikuti pembelajaran $P Q 4 R$ lebih rendah dari siswa yang mengikuti pembelajaran konvensional.

Selanjutnya dilakukan uji proporsi terhadap data kemampuan berpikir reflektif matematis akhir siswa untuk mengetahui proporsi siswa dengan kemampuan berpikir reflektif matematis minimal pada kategori sedang. Berdasarkan skor posttest siswa yang mengikuti pembelajaran $P Q 4 R$ didapatkan $\bar{x}=36,1$ dan $s=3,65$, sehingga interpretasi kategori skor kemampuan berpikir reflektif matematis tersaji dalam Tabel 3.

Tabel 3. Interpretasi skor kemampuan berpikir reflektif matematis

\begin{tabular}{ccc}
\hline Interval Skor & Interpretasi & Frekuensi \\
\hline $39,75 \leq x$ & Tinggi & 7 \\
$32,45 \leq x<39,75$ & Sedang & 19 \\
$x<32,75$ & Rendah & 4 \\
\hline
\end{tabular}

Tabel 3 menunjukkan bahwa dari 30 siswa, sebagian besar siswa memiliki kemampuan berpikir reflektif pada kategori sedang, setelah diterapkan metode pembelajaran $P Q 4 R$. Selanjutnya untuk menguji apakah proporsi siswa yang memiliki kemampuan berpikir reflektif pada kategori minimal sedang lebih dari $60 \%$, maka dilakukan uji $z$. Sebelum dilakukan uji $z$, terlebih dahulu dilakukan uji normalitas data. Dari hasil uji normalitas diperoleh $\chi^{2}=1,56$ dan $\chi^{2}$ tabel $=11,1$. Karena $\chi^{2} \leq \chi^{2}$ tabel maka $\mathrm{H}_{0}$ diterima, sehingga dapat disimpulkan bahwa data kemampuan berpikir reflektif matematis siswa pada kelas yang diterapkan metode $P Q 4 R$ berdistribusi normal. Selanjutnya dilakukan pengujian hipotesis sebagai berikut:

$H_{0}: \pi=60 \%$ (Persentase siswa dengan pembelajaran PQ4R yang memiliki kemampuan berpikir reflektif terkategori minimal sedang sama dengan $60 \%$ ) 
$\mathrm{H}_{1}: \pi>60 \%$ (Persentase siswa dengan pembelajaran PQ4R yang memiliki kemampuan berpikir reflektif terkategori minimal sedang lebih dari 60\%)

Dari data sampel diperoleh $z=2,98$ dan $z_{0,05}=1,645$ sehingga $H_{0}$ ditolak. Artinya, persentase siswa pada kelas $P Q 4 R$ dengan kemampuan berpikir reflektif matematis terkategori minimal sedang lebih dari $60 \%$ dari jumlah siswa.

Selanjutnya dilakukan pengujian hipotesis untuk melihat perbedaan peningkatan kemampuan berpikir reflektif pada kelas $P Q 4 R$ dan konvensional. Hipotesis yang diuji sebagai berikut.

$\mathrm{H}_{0}: \mu_{1}=\mu_{2}$ (Peningkatan kemampuan berpikir reflektif siswa kelas PQ4R sama dengan siswa pada kelas konvensional)

$\mathrm{H}_{1}: \mu_{1} \neq \mu_{2}$ (Peningkatan kemampuan berpikir reflektif siswa kelas $P Q 4 R$ berbeda dengan siswa pada kelas konvensional)

Hasil analisis data gain kelas PQ4R diperoleh $\chi^{2}=3,09$ dan pada kelas konvensional $\chi^{2}=6,18$. Karena nilai $\chi^{2}$ lebih dari nilai $\chi^{2}$ tabel $=11,1$ maka dapat disimpulkan bahwa data pada kedua kelas berdistribusi normal. Hasil pengujian kesamaan varians kedua kelas memperoleh nilai $F=0,519$ dan $F$ tabel $=2,101$. Hasil tersebut menunjukkan bahwa data dari kedua kelas adalah homogen. Dengan menggunakan uji- $t$ pada taraf signifikansi $\alpha=0,05$ diperoleh nilai $t=0,48$ dan $t$ tabel $=1,67$ sehingga tidak cukup bukti untuk menolak $\mathrm{H}_{0}$. Hal ini menunjukkan bahwa rata-rata peningkatan kemampuan berpikir reflektif matematis siswa yang mengikuti pembelajaran $P Q 4 R$ tidak berbeda signifikan dengan peningkatan kemampuan berpikir reflektif matematis siswa yang mengikuti pembelajaran konvensional.

\section{Efektivitas Model Pembelajaran PQ4R Ditinjau dari Self-Concept Siswa}

Deskripsi self-concept siswa yang mendapat perlakuan pembelajaran $P Q 4 R$ dan pembelajaran konvensional disajikan pada Tabel 4.

Tabel 4. Deskripsi self-concept siswa

\begin{tabular}{lcccccc}
\hline \multirow{2}{*}{ Kelas } & \multicolumn{2}{c}{ Pretest } & \multicolumn{2}{c}{ Posttest } & \multicolumn{2}{c}{ Gain } \\
\cline { 2 - 7 } & $\bar{x}$ & $s$ & $\bar{x}$ & $s$ & $\bar{x}$ & $s$ \\
\hline PQ4R & 44,83 & 7,63 & 47,60 & 8,31 & 0,07 & 0,23 \\
Konvensional & 44,17 & 10,04 & 46,07 & 9,83 & 0,05 & 0,16 \\
\hline
\end{tabular}

Berdasarkan Tabel 4 dapat dilihat bahwa rata-rata skor self-concept siswa yang mengikuti pembelajaran $P Q 4 R$ lebih tinggi daripada rata-rata skor self-concept siswa yang mengikuti pembelajaran konvensional. Simpangan baku skor self-concept siswa yang mengikuti pembelajaran $P Q 4 R$ lebih rendah daripada simpangan baku skor self-concept siswa yang mengikuti pembelajaran konvensional. Hal ini berarti persebaran skor self-concept siswa yang mengikuti pembelajaran konvensional lebih beragam daripada skor self-concept siswa yang mengikuti pembelajaran $P Q 4 R$.

Pada Tabel 4 diketahui bahwa rata-rata self-concept akhir siswa yang mengikuti pembelajaran $P Q 4 R$ lebih tinggi daripada rata-rata skor self-concept akhir siswa yang mengikuti pembelajaran konvensional. Simpangan baku skor self-concept akhir siswa yang mengikuti pembelajaran PQ4R lebih rendah daripada simpangan baku skor selfconcept akhir siswa yang mengikuti pembelajaran konvensional. Hal ini berarti persebaran skor self-concept akhir siswa yang mengikuti pembelajaran konvensional lebih beragam daripada siswa yang mengikuti pembelajaran PQ4R.

Data peningkatan (gain) self-concept siswa diperoleh dari selisih antara skor akhir dan skor awal kemudian dibagi dengan selisih antara skor maksimal dan skor awal self-concept. Berdasarkan Tabel 4 diketahui bahwa ratarata skor gain self-concept siswa yang mengikuti pembelajaran $P Q 4 R$ sedikit lebih tinggi dibanding rata-rata skor gain self-concept siswa yang mengikuti pembelajaran konvensional. Simpangan baku skor gain self-concept siswa yang mengikuti pembelajaran $P Q 4 R$ juga sedikit lebih tinggi dibanding rata-rata skor gain self-concept siswa yang mengikuti pembelajaran konvensional. Hal ini menunjukkan bahwa persebaran skor gain self-concept siswa yang mengikuti pembelajaran $P Q 4 R$ lebih beragam dibanding siswa yang mengikuti pembelajaran konvensional.

Analisis setiap indikator dilakukan pada data skor pretest dan posttest pada kelas eksperimen dan kelas kontrol. Adapun hasil analisis setiap indikator pada kelas eksperimen dan kelas kontrol disajikan Tabel 5. 
PYTHAGORAS: Jurnal Pendidikan Matematika, 15 (1), 2020 - 68

Intan Permatasari, Sri Hastuti Noer, Pentatito Gunowibowo

Tabel 5. Persentase pencapaian indikator self-concept siswa

\begin{tabular}{lcccc}
\hline \multirow{2}{*}{ Indikator } & \multicolumn{2}{c}{ Pretest } & \multicolumn{2}{c}{ Posttest } \\
\cline { 2 - 5 } & Eksperimen & Konvensional & Eksperimen & Konvensional \\
\hline Pengetahuan & $53 \%$ & $56 \%$ & $57 \%$ & $57 \%$ \\
Harapan & $64 \%$ & $60 \%$ & $67 \%$ & $65 \%$ \\
Penilaian & $56 \%$ & $55 \%$ & $59 \%$ & $56 \%$ \\
Rata-rata & $58 \%$ & $57 \%$ & $61 \%$ & $59 \%$ \\
\hline
\end{tabular}

Berdasarkan Tabel 5 diketahui bahwa self-concept awal siswa yang mengikuti pembelajaran $P Q 4 R$ pada masingmasing indikator lebih tinggi dibandingkan siswa yang mengikuti pembelajaran konvensional, kecuali pada indikator pengetahuan. Dapat dilihat juga bahwa pencapaian self-concept akhir siswa yang mengikuti pembelajaran $P Q 4 R$ pada indikator harapan dan penilaian juga lebih tinggi dibandingkan siswa yang mengikuti pembelajaran konvensional, sedangkan pada indikator pengetahuan, pencapaian kedua kelas sama besar. Pencapaian tertinggi self-concept siswa pada kedua kelas berada pada indikator harapan. Pencapaian terendah self-concept siswa yang mengikuti pembelajaran $P Q 4 R$ berada pada indikator pengetahuan, sedangkan pencapaian terendah self-concept siswa yang mengikuti pembelajaran konvensional berada pada indikator penilaian.

Selanjutnya dilakukan uji proporsi terhadap data self-concept akhir siswa untuk mengetahui apakah proporsi siswa dengan self-concept terkategori minimal sedang lebih dari $60 \%$ dari jumlah siswa kelas tersebut. Berdasarkan skor posttest siswa yang mengikuti pembelajaran $P Q 4 R$ didapatkan $\bar{x}=47,6$ dan $s=8,31$, sehingga interpretasi kategori skor self-concept matematis disajikan pada Tabel 6.

Tabel 6. Interpretasi kategori self-concept siswa

\begin{tabular}{ccc}
\hline Interval Skor Self-concept & Interpretasi & Frekuensi \\
\hline $55,91 \leq x$ & Tinggi & 6 \\
$39,29 \leq x<55,91$ & Sedang & 19 \\
$x<39,29$ & Rendah & 5 \\
\hline
\end{tabular}

Tabel 6 menunjukkan bahwa dari 30 siswa, sebagian besar siswa memiliki self-concept pada kategori sedang, setelah diterapkan metode pembelajaran $P Q 4 R$. Selanjutnya untuk menguji apakah proporsi siswa yang memiliki self-concept pada kategori minimal sedang lebih dari $60 \%$, maka dilakukan uji $z$. Sebelum dilakukan uji $z$, terlebih dahulu dilakukan uji normalitas data. Hasil uji normalitas terhadap data self-concept siswa diperoleh $\chi^{2}=1,65$ dan $\chi^{2}$ tabel $=11,1$. Karena $\chi^{2} \leq \chi^{2}$ tabel maka $\mathrm{H}_{0}$ diterima, sehingga dapat disimpulkan bahwa data self-concept siswa pada kelas yang diterapkan metode $P Q 4 R$ berdistribusi normal. Selanjutnya dilakukan pengujian hipotesis sebagai berikut:

$\mathrm{H}_{0}: \pi=60 \%$ (Persentase siswa dengan pembelajaran PQ4R yang memiliki self-concept terkategori minimal sedang sama dengan $60 \%$ )

$\mathrm{H}_{1}: \pi>60 \%$ (Persentase siswa dengan pembelajaran PQ4R yang memiliki self-concept terkategori minimal sedang lebih dari $60 \%)$

Dari data sampel diperoleh $z=2,61$ dan $z_{0,05}=1,645$ sehingga $H_{0}$ ditolak. Artinya, persentase siswa pada kelas $P Q 4 R$ dengan self-concept terkategori minimal sedang lebih dari $60 \%$ dari jumlah siswa.

Selanjutnya dilakukan pengujian hipotesis untuk melihat perbedaan peningkatan self-concept siswa pada kelas $P Q 4 R$ dan konvensional. Hipotesis yang diuji sebagai berikut.

$\mathrm{H}_{0}: \mu_{1}=\mu_{2}$ (Peningkatan self-concept siswa kelas $P Q 4 R$ sama dengan siswa pada kelas konvensional)

$\mathrm{H}_{1}: \mu_{1} \neq \mu_{2}$ (Peningkatan self-concept siswa kelas $P Q 4 R$ berbeda dengan siswa pada kelas konvensional) Hasil analisis data gain self-concept kelas PQ4R diperoleh $\chi^{2}=2,55$ dan pada kelas konvensional $\chi^{2}=4,27$. Karena nilai $\chi^{2}$ lebih dari nilai $\chi^{2}$ tabel $=11,1$ maka dapat disimpulkan bahwa data self-concept pada kedua kelas berdistribusi normal. Hasil pengujian kesamaan varians kedua kelas memperoleh nilai $F=0,478$ dan $F$ tabel $=2,101$. Hasil tersebut menunjukkan bahwa data dari kedua kelas adalah homogen. Dengan menggunakan uji-t pada taraf signifikansi $\alpha=0,05$ diperoleh nilai $t=0,50$ dan $t$ tabel $=1,67$ sehingga tidak cukup bukti untuk menolak $H_{0}$. Hal ini menunjukkan bahwa rata-rata peningkatan self-concept siswa yang mengikuti pembelajaran $P Q 4 R$ tidak berbeda signifikan dengan peningkatan self-concept siswa yang mengikuti pembelajaran konvensional. 


\section{PEMBAHASAN}

Temuan penelitian menunjukkan bahwa proporsi siswa pada kelas $P Q 4 R$ dengan kemampuan berpikir reflektif matematis pada kategori minimal sedang lebih dari $60 \%$ dari jumlah keseluruhan siswa, namun rata-rata peningkatan kemampuan berpikir reflektif matematis siswa yang mengikuti pembelajaran $P Q 4 R$ tidak lebih tinggi daripada rata-rata peningkatan kemampuan berpikir reflektif matematis siswa yang mengikuti pembelajaran konvensional. Dengan demikian, metode pembelajaran $P Q 4 R$ tidak efektif ditinjau dari kemampuan berpikir reflektif matematis siswa. Temuan penelitian juga menunjukkan bahwa proporsi siswa pada kelas $P Q 4 R$ dengan selfconcept pada kategori minimal sedang juga lebih dari $60 \%$ dari jumlah keseluruhan siswa, namun rata-rata peningkatan self-concept siswa yang mengikuti pembelajaran $P Q 4 R$ tidak lebih baik dibandingkan rata-rata peningkatan self-concept siswa yang mengikuti pembelajaran konvensional. Kemampuan berpikir reflektif dan self-concept siswa yang mengikuti pembelajaran $P Q 4 R$ tidak lebih baik daripada self-concept siswa yang mengikuti pembelajaran konvensional diduga kuat karena metode pembelajaran $P Q 4 R$ merupakan metode pembelajaran yang baru bagi siswa dan pelaksanaannya relatif singkat, sehingga siswa belum terbiasa belajar menggunakan metode ini. $\mathrm{Hal}$ ini sesuai dengan pendapat Pratiwi (2010) yang mengatakan bahwa self-concept terbentuk dalam waktu yang relatif lama dan pembentukan self-concept tidak dapat dilakukan dengan perlakuan yang tidak biasa dalam diri seseorang.

Jika ditinjau dari tiap indikator kemampuan berpikir reflektif, pencapaian tertinggi dari kedua kelas sebelum perlakuan ada pada indikator reacting. Hal ini menunjukkan bahwa sebelum ada perlakuan siswa cukup mampu dalam menanggapi permasalahan berdasarkan informasi yang diberikan. Kemudian pencapaian terendah pada kedua kelas terletak pada indikator contemplating. Hal ini menunjukkan bahwa siswa belum mampu dalam menguraikan dan menginformasikan jawaban dari masalah yang diberikan serta menganalisis kebenaran darijawaban tersebut. Setelah dilakukan penerapan pembelajaran $P Q 4 R$ terdapat peningkatan pada masing-masing indikator kemampuan berpikir reflektif matematis. Hal ini menunjukkan kemampuan siswa dalam menanggapi permasalahan yang diberikan, mengklarifikasi informasi untuk mengevaluasi apa yang diyakini, menguraikan, menginformasikan, serta menganalisis kebenaran dari jawaban, dapat meningkat dari kemampuan awal. Pelaksanaan pembelajaran $P Q 4 R$ diawali dengan tahap preview.

Pada tahap ini siswa membaca judul materi dan sub-sub judul materi untuk menemukan ide-ide pokok pada bahan ajar dan menuliskannya di LKPD. Selanjutnya pada tahap question siswa membuat pertanyaan dari ide-ide pokok yang dituliskan di LKPD. Kemudian siswa membaca pemahaman dari keseluruhan bahan bacaan yang dipelajari sehingga siswa menemukan jawaban terhadap pertanyaan yang telah dibuat (tahap read). Melalui kegiatan ini siswa dibiasakan untuk secara aktif melakukan kegiatan, aktif membaca dan mengkonstruksi sendiri pengetahuan yang dimilikinya melalui LKPD dan bahan ajar yang diberikan. Hal ini sejalan dengan pendapat Trianti (Jatisunda, 2017) yang menyatakan bahwa dalam pembelajaran konstruktivisme, siswa membangun sendiri pengetahuan melalui keterlibatan aktif pada kegiatan pembelajaran. Hal tersebut dapat meningkatkan indikator kemampuan berpikir reflektif yaitu reacting.

Tahap selanjutnya pada pembelajaran $P Q 4 R$ adalah reflect, yaitu siswa menghubungkan pengetahuan yang sudah mereka miliki melalui kegiatan membaca pemahaman untuk memecahkan masalah yang disediakan pada LKPD. Hamalik (2013) mengemukakan salah satu cara menyelesaikan masalah adalah dengan menghubungkan masalah yang sedang dihadapi dengan pengetahuan yang sudah dimiliki sebelumnya. Salah satu cara yang dilakukan untuk membantu siswa dalam menghubungkan masalah dengan pengetahuan lamanya yaitu dengan memberikan pertanyaan-pertanyaan yang sesuai dengan masalah yang sedang dihadapi. Oleh karena itu, tahap ini mampu meningkatkan indikator kemampuan berpikir reflektif yaitu comparing.

Tahap selanjutnya yaitu recite, yaitu siswa membuat rangkuman dari bahan bacaan yang telah dipelajari dan dituliskan pada LKPD. Kemudian siswa memeriksa dan membaca kembali rangkuman yang telah dibuat untuk melakukan peninjauan terhadap kelengkapan pada tahap recite dan merumuskan kesimpulan dan pembelajaran (tahap review). Melalui kedua kegiatan tersebut siswa dibiasakan untuk mengkonstruk pengetahuan baru, mengecek informasi lama dan merevisinya jika tidak sesuai. Hal ini sejalan dengan pendapat Trianto (2007) yang menyatakan bahwa siswa harus menemukan sendiri dan mentransformasikan informasi kompleks, mengecek informasi baru dengan aturan-aturan lama dan merevisinya apabila aturan-aturan itu tidak lagi sesuai. Hal ini mampu meningkatkan kemampuan berpikir reflektif yaitu contemplating. 
Meskipun setiap indikator kemampuan berpikir reflektif siswa yang mengikuti pembelajaran PQ4R mengalami peningkatan, namun peningkatan tersebut tidak lebih tinggi dibandingkan dengan siswa yang mengikuti pembelajaran konvensional. Pencapaian indikator comparing pada siswa yang mengikuti pembelajaran PQ4R lebih rendah daripada siswa yang mengikuti pembelajaran konvensional. Hal tersebut terjadi karena siswa yang mengikuti pembelajaran $P Q 4 R$ tidak mengikuti instruksi yang terdapat pada masalah yang diberikan. Saat menyelesaikan masalah, sebagian besar siswa yang mengikuti pembelajaran $P Q 4 R$ tidak memberikan alasan dalam memilih metode penyelesaian yang benar. Berbeda dengan siswa yang mengikuti pembelajaran konvensional, sebagian besar siswa memberikan alasan untuk setiap metode yang dipilih, sehingga pencapaian indikator comparing siswa yang mengikuti kelas $P Q 4 R$ kurang maksimal.

Pada pertemuan pertama, guru memberikan bahan bacaan dan LKPD secara bersamaan kepada siswa. Akan tetapi, siswa cenderung lebih tertarik langsung melakukan penyelesaian masalah dalam LKPD. Akibatnya siswa belum mampu menghubungkan materi-materi yang sudah mereka miliki untuk memecahkan masalah yang terdapat dalam LKPD. Sehingga, siswa lebih banyak bertanya kepada guru bagaimana penyelesaian permasalahan dalam LKPD. Kemudian guru harus menjelaskan kembali terkait pembelajaran PQ4R. Hal tersebut membuat kegiatan belajar siswa berlangsung cukup lambat, sehingga waktu siswa untuk membuat rangkuman dari bahan bacaan yang telah dipelajari (tahap recite) dan melakukan review materi tidak maksimal. Akibatnya, masih ada sebagian siswa yang belum benar-benar memahami materi yang dipelajari pada pertemuan pertama, sehingga guru kembali membahas cukup banyak materi pertemuan pertama pada pertemuan kedua. Pada pertemuan kedua, ketiga, dan keempat siswa sudah mulai mengerti dan memahami terkait pembelajaran $P Q 4 R$. Ketika guru memberikan bahan bacaan dan LKPD secara bersamaan, siswa tidak lagi mengulangi kesalahan pada pertemuan pertama, sehingga setiap tahap dalam metode pembelajaran $P Q 4 R$ secara umum dilalui dengan baik oleh siswa.

Berbeda dengan pembelajaran $P Q 4 R$, pada pembelajaran konvensional siswa melakukan serangkaian aktivitas yang terdapat dalam buku siswa. Kemudian siswa diminta untuk mengajukan pertanyaan dan siswa lain diminta untuk menjawab. Sebagian besar siswa mengajukan pertanyaan yang sudah ada dalam buku siswa. Kemudian setelah tidak ada lagi siswa yang bertanya selanjutnya siswa mengerjakan latihan yang terdapat dalam buku siswa. Di akhir kegiatan belajar, siswa dipilih secara acak untuk mempresentasikan hasil pengerjaannya dan siswa lain memberi sanggahan maupun komentar jika hasil kerja temannya belum sesuai.

Berdasarkan proses belajar konvensional tersebut, siswa memiliki kesempatan yang lebih sedikit untuk mengembangkan kemampuan berpikir reflektif jika dibandingkan dengan siswa yang mengikuti pembelajaran $P Q 4 R$. Siswa mendapat sedikit kesempatan untuk menanggapi permasalahan yang diberikan, melakukan proses menguraikan, menginformasikan serta menganalisis kebenaran dari jawaban dan melakukan klarifikasi untuk mengevaluasi apa yang diyakini. Akibatnya, persentase pencapaian indikator kemampuan berpikir reflektif pada siswa yang mengikuti pembelajaran $P Q 4 R$ lebih tinggi dibandingkan siswa yang mengikuti pembelajaran konvensional.

\section{SIMPULAN}

Penelitian ini menyimpulkan bahwa metode pembelajaran $P Q 4 R$ tidak efektif ditinjau dari kemampuan berpikir reflektif dan self-concept siswa kelas VIII pada salah satu SMP Negeri di Bandar Lampung, meskipun persentase siswa pada kelas $P Q 4 R$ dengan kemampuan berpikir reflektif dan self-concept terkategori minimal sedang lebih dari $60 \%$. Berdasarkan hasil penelitian ini, peneliti menyarankan beberapa hal. Pertama, kepada para guru yang akan menerapkan metode pembelajaran $P Q 4 R$, guru harus mampu memberikan pemahaman dan pengertian kepada siswa mengenai tahapan belajar dengan metode pembelajaran $P Q 4 R$, serta memperhatikan keterlibatan seluruh siswa dalam setiap tahapan pembelajaran $P Q 4 R$. Kedua, kepada peneliti lainnya yang akan melakukan penelitian tentang pembelajaran $P Q 4 R$, disarankan untuk memperhatikan pengelolaan kelas dan efisien waktu dalam setiap tahapan belajar pembelajaran $P Q 4 R$, sehingga proses pembelajaran dapat berjalan secara optimal. Selain itu, penelitian serupa juga perlu dilakukan dengan melibatkan populasi dan sampel yang lebih luas, sehingga dapat dilakukan generalisasi yang lebih luas terkait dampak penerapan $P Q 4 R$ pada pembelajaran matematika.

\section{DAFTAR PUSTAKA}

Angkotasan, N. (2013). Model PBL dan cooperative learning tipe TAI ditinjau dari aspek kemampuan berpikir reflektif dan pemecahan masalah matematis. Pythagoras: Jurnal Pendidikan Matematika, 8(1), 92-100. https://doi.org/10.21831/pg.v8i1.8497 
Apino, E., \& Retnawati, H. (2017). Developing instructional design to improve mathematical higher order thinking skills of students. Journal of Physics: Conference Series, 812(1), 1-7. https://doi.org/10.1088/17426596/812/1/012100

Arifin, Z. (2012). Evaluasi pembelajaran. Remaja Rosdakarya.

Arikunto, S. (2011). Prosedur penelitian: Suatu pendekatan praktik. Rineka Cipta.

Azwar, S. (2016). Penyusunan skala psikologi. Pustaka Pelajar.

Deringol, Y. (2019). The relationship between reflective thinking skills and academic achievement in mathematics in fourth-grade primary school student. International Online Journal of Education and Teaching. 6(3), 613622. https://iojet.org/index.php/IOJET/article/view/532

Fuady, A. (2017). Berpikir reflektif dalam pembelajaran matematika. Jurnal Ilmiah Pendidikan Matematika. 1(2), 104-112. https://doi.org/10.26877/jipmat.v1i2.1236

Ghufron, M. N., \& Risnawita, S. R. (2010). Teori-teori psikologi. Ar Ruzz Media.

Hamalik, O. (2013). Proses belajar mengajar. Bumi Aksara.

Inawati, I., \& Sanjaya, M. D. (2018). Kemampuan membaca cepat dan pemahaman siswa kelas V SD Negeri Oku. Jurnal Bindo Sastra 2(1), 104-112. https://doi.org/10.32502/jbs.v2i1.927

Jailani, J., Sugiman, S., \& Apino, E. (2017). Implementing the problem-based learning in order to improve the students' HOTS and characters. Jurnal Riset Pendidikan Matematika, 4(2), 247-259. https://doi.org/10.21831/jpmm.v4i2.17674

Jatisunda, M. G. (2017). Hubungan self-efficacy siswa SMP dengan kemampuan pemecahan masalah matematis. Jurnal THEOREMS (The Original Research of Mathematics), 1(2), 24-30.

https://www.jurnal.unma.ac.id/index.php/th/article/view/375/355

Kemendikbud. (2014). Lampiran III Permendikbud Nomor 58 Tahun 2014 tentang Kurikulum 2013 Sekolah Menengah Pertama/Madrasah Tsanawiyah.

Noer, S. H. (2010). Peningkatan kemampuan berpikir kritis, kreatif, dan reflektif(K2R) matematis siswa SMP melalui pembelajaran berbasis masalah [Doctoral dissertation, Universitas Pendidikan Indonesia]. http://repository.upi.edu/8502/

Noer, S. H. (2017). Strategi pembelajaran matematika. Graha Ilmu.

Novalia, H., \& Noer, S. H. (2019). Pengembangan modul pembelajaran matematika dengan strategi PQ4R untuk meningkatkan kemampuan berpikir kreatif dan kemandirian belajar siswa SMA. Jurnal Penelitian dan Pembelajaran Matematika, 12(1), 51-65. http://dx.doi.org/10.30870/jppm.v12i1.4854

Nuriadin, I., Kusuma, Y. S., Sabandar, J., \& Dahlan, J. A. (2015). Enhancing of students mathematical reflective thinking ability through knowledge sharing learning strategy in senior high school. International Journal of Education and Research. 3(9), 255-268. http://www.ijern.com/journal/2015/September-2015/21.pdf

OECD. (2019), PISA 2018 results (Volume 1): What students know and can do. OECD Publishing. https://doi.org/10.1787/5f07c754-en.

Pabalik, D., Ibrahim, I., Puji, R., \& Wekke, I. S. (2020). PQ4R strategy and information technology in enhancing students reading comprehension at junior high school West Papua Indonesia. International Journal of Advanced Science and Technology. 29(5), 6722-6734. http://sersc.org/journals/index.php/IJAST/article/view/17724

Peteros, E., Gamboa, A., Etcuban, J. O., Dinauanao, A., Sitoy, R., \& Arcadio, R. (2020). Factors affecting mathematics performance of junior high school students. International Electronic Journal of Mathematics Education. 15(1), 1-13. https://doi.org/10.29333/iejme/5938

Presiden Republik Indonesia. (2013). Peraturan Pemerintah Nomor 32 Tahun 2013 tentang Perubahan Peraturan Pemerintah Nomor 19 Tahun 2005 tentang Standar Nasional Pendidikan. https://jdih.setkab.go.id/PUUdoc/173768/PP0322013.pdf 
Pratiwi, D. A. (2010). PBL dengan metode proyek dan resitasi ditinjau dari kreativitas dan konsep dirisiswa [Master's thesis, Universitas Sebelas Maret]. https://eprints.uns.ac.id/3569/

Rahmawati, R. (2016). Indonesia dalam PISA dan TIMSS. Disampaikan dalam Seminar Nasional Hasil Survei PISA 2015.

Republik Indonesia. (2003). Undang-Undang Republik Indonesia Nomor 20 Tahun 2003 tentang Sistem Pendidikan Nasional.

Retnawati, H., Djidu, H., Kartianom, K., Apino, E., \& Anazifa, R. D. (2018). Teachers' knowledge about higher-order thinking skills and its learning strategy. Problems of Education in the 21st Century, 76(2), 215-230. http://oaji.net/articles/2017/457-1524597598.pdf

Rusman, R. (2012). Model-model pembelajaran. Grafindo Persada.

Siregar, R., \& Humairo, F. (2018). The effect of self-concept on the mathematics learning achievement. International Journal on Language, Research and Education Studies. 2(2), 218-227. http://jurnal.uinsu.ac.id/index.php/ijlres/article/view/1647/1327

Subyantoro, S. (2011). Pengembangan keterampilan membaca cepat. Graha Ilmu.

Sudijono, A. (2011). Pengantar evaluasi pendidikan. Rajawali Pers.

Sudjana, N. (2004). Dasar-dasar proses belajar mengajar. Remaja Rosdakarya.

Suharna, H. (2012). Berpikir reflektif (reflective thinking) siswa SD berkemampuan matematika tinggi dalam pemahaman masalah pecahan. Prosiding Seminar Nasional Matematika dan Pendidikan Matematika Jurusan Pendidikan Matematika FMIPA UNY. https://eprints.uny.ac.id/7660/

Suntoro, A. (2009). Eksperimen pembelajaran matematika menggunakan pendekatan konstruktivistik dengan multimedia komputer ditinjau dari aktivitas belajar siswa kelas VIII [Doctoral disertation, Universitas Sebelas Maret]. https://eprints.uns.ac.id/8166/

Suprijono, A. (2013). Cooperative learning teori \& aplikasi PAIKEM. Pustaka Pelajar.

Triana, M. (2017). Pengembangan lembar kerja peserta didik berbasis inkuiri untuk meningkatkan kemampuan berpikir kreatif matematis dan self concept siswa. [Unpublished master's thesis]. Universitas Lampung.

Trianto, T. (2007). Model-model pembelajaran inovatif berorientasi konstruktivistik. Prestasi Pustaka.

Trianto. T. (2015). Mendesain model pembelajaran inovatif, progesif, dan kontekstual. Prenadamedia Group.

Wungkana, M. (2016). Upaya meningkatkan kemampuan membaca pemahaman dengan metode PQ4R pada siswa kelas V SDN Inpres I Tatura. Jurnal Kreatif Tadulako, 4(6), 332-339.

Yulianti, W., Sulistyaningsih, D., \& Mawarsari, V. D. (2016). Keefektifan model pembelajaran kooperatif tipe priview question read reflect recite review dengan pendekatan problem solving terhadap kemampuan pemahaman konsep pada materi geometri kelas X. Jurnal Karya Pendidikan Matematika, 3(1), 27-38. https://doi.org/10.26714/jkpm.3.1.2016.\%25p 